\title{
Contributors
}

\author{
Emanuelle Brandström Arellano
}

PhD Researcher, School of Global Studies, University of Gothenburg, Sweden.

\section{Elisa Fornalé}

Swiss National Science Foundation Professor, World Trade Institute, University of Bern, Switzerland.

\section{Anja K. Franck}

Senior Lecturer, School of Global Studies, University of Gothenburg, Sweden.

\section{Flavia Jurje}

Senior Researcher, Global Studies Institute, University of Geneva, and Guest Lecturer, Swiss Graduate School of Public Administration, University of Lausanne, Switzerland.

\section{Sandra Lavenex}

Professor of European and International Politics, University of Geneva, Switzerland, and Visiting Professor, College of Europe, Natolin Campus, Poland.

\section{Eszter Lukács}

Associate Professor and Vice-Rector for Educational Affairs, Széchenyi István University, Győr, Hungary.

\section{Sebastien Moretti}

Senior Fellow, Global Migration Centre, Graduate Institute of International and Development Studies, Geneva, Switzerland, and former Visiting Research Scholar, Refugee Studies Centre (RSC), Oxford University, United Kingdom.

\section{Nicola Piper}

Professor of International Migration, Director of the Sydney Asia Pacific Migration Centre, University of Sydney, Australia.

\section{Stefan Rother}

Researcher and Lecturer, Political Science Seminar, University of Freiburg, Germany. 
Jürgen Rüland

Professor, Chair of International Relations, Political Science Seminar, University of Freiburg, Germany.

\section{Julian Schwabe}

Lecturer and Researcher, Department of Geography, Philipps-University of Marburg, Germany.

\section{Joseph Trawicki Anderson}

$\mathrm{PhD}$ Researcher, School of Global Studies, University of Gothenburg, Sweden.

\section{Katalin Völgyi}

Research Fellow, Institute of World Economics, Hungarian Academy of Sciences, and Assistant Professor, Széchenyi István University, Győr, Hungary. 